\title{
MORFODINÂMICA FLUVIAL CENOZÓICA EM ZONAS DE CONTATO ENTRE FAIXAS MÓVEIS E "CUNHAS TECTÓNICAS" NA REGIÃO SUL DE MINAS GERAIS
}

\author{
Antônio Pereira Magalhães Jr $(*)$ \& Elaine de Sousa Trindade (**)
}

\begin{abstract}
RESUMO
Os vales fluviais da região sul de Minas Gerais têm sido marcados por uma evolução geomorfológica cenozóica condicionada por fortes influências tectônicas das faixas móveis da porção oriental do país (Sistema Serra do Mar/Serra da Mantiqueira). O condicionamento sobre os ciclos morfodinâmicos tem englobado a reativação de zonas de cisalhamento pré-cambrianas como a Zona Rúptil CarandaíMogi Guaçu (Wernick et al, 1981), responsável pela formação de grabens que "capturam” os níveis de base locais. A bacia do rio Sapucaí, um dos principais afluentes do rio Grande, está inserida em um contexto tectônico no qual alternam-se blocos de comportamento diferencial: zonas de cisalhamento e sistemas horst-grabens, e blocos estabilizados alóctones ("cunhas tectônicas"). Este trabalho apresenta a integração de resultados de diversos estudos sobre a reconstituição da dinâmica fluvial cenozóica de bacias fluviais na região sul de Minas Gerais, com base em análise estratigráfica de seqüências aluviais e sua correlação com o quadro geotectônico regional. Mesmo que situada no contexto de relativa estabilidade do Escudo Brasileiro, a região destaca-se como um rico cenário para a identificação de influências tectônicas sobre o quadro geomorfológico nacional.
\end{abstract}

\begin{abstract}
The fluvial valleys of the southern region of Minas Gerais have been marked by a geomorphologic cenozoic evolution, conditioned by strong tectonic influences from the mobile belt in the eastern part of the country (Serra do Mar - Serra da Mantiqueira system). The influence over the morphodynamic cycles has involved the reactivation of Precambrian shear zones such as the Rúptil Zone Carandaí-MogiGuaçu (Wernick et al, 1981), responsible for the formation of grabens which "reach" the local base levels. The Sapucaí river basin, one of the major tributaries of the Grande River, is inserted in a tectonic blocks context wich differential behavior: shear zones, horst-graben systems, and stabilized tectonic blocks. This work presents the integration of results from several studies on the reconstitution of the fluvial basins in the southern part of Minas Gerais, based in the stratigraphic analysis of alluvial sequences and its correlation with the regional geotectonic framework. Even though it is located in the relative stability of the Brazilian Shield, the region stands out as a rich scenario for the identification of tectonic influences on the national geomorphologic framework.
\end{abstract}

\section{INTRODUÇ̃̃o}

Inserida no domínio estável do Escudo Brasileiro, a região sul de Minas Gerais apresenta importantes registros da evolução morfodinâmica de vales fluviais condicionados por blocos tectônicos de comportamento diferencial ao longo do Cenozóico. Para a compreensão deste passado "recente", as seqüências estratigráficas, a morfologia e a configuração da rede de drenagem são evidências relevantes em um contexto climático desfavorável à preservação de vestígios paleogeomorfológicos. Sua organização espacial e sua correlação com o quadro geológico regional revelam marcos espaço-temporais dos eventos deposicionais edenudacionais regionais.
Este trabalho integra um conjunto de resultados de estudos sobre as relações entre a dinâmica fluvial cenozóica em sub-bacias contribuintes da bacia hidrográfica do rio Sapucaí, região sul de Minas Gerais (bacias dos rios Mandu, Cervo e Turvo), e o quadro geotectônico regional. Os estudos envolveram a interpretação de níveis deposicionais aluviais e a análise estratigráfica de seqüências aluviais. A região destaca-se como um rico cenário para a identificação de influências tectônicas sobre o quadro geomorfológico nacional, considerando sua posição estratégica em uma porção do Escudo Brasileiro, marcada pela sucessão de blocos estabilizados e blocos e faixas móveis reativados no Cenozóico. 


\section{METODOLOGIA}

O trabalho baseou-se na análise de cartas topográficas (1:50.000) e imagens de satélite TM LANDSAT 5-banda 4 (1:100.000), em fotointerpretação (CEMIG, 1989, 1:30.000) e levantamentos de campo para a identificação e análise estratigráfica de formações superficiais. Em alguns depósitos aluviais préselecionados foram realizadas análises granulométricas e de conteúdo de matéria orgânica (método Walkley Black), bem como análises de difração de raios-X para identificação de argilas (IGC/UFMG).

Enquanto as seqüências sedimentares permitiram a reconstituição de eventos morfodinâmicos, a análise cartográfica auxiliou a correlação de aspectos morfológicos, padrões fluviais e direções da rede de drenagem, facilitando a compartimentação de bacias fluviais em domínios geomorfológicos homogêneos. Foi elaborado um mapa morfotectônico que permite correlacionar a organização do quadro geomorfológico regional com o contexto geotectônico.

\section{QUADROMORFOTECTÔNICOREGIONAL}

As bacias fluviais estudadas situam-se na porção sul de Minas Gerais, bacia hidrográfica do rio Sapucaí (Fig. 1). A região apresenta clima tropical úmido e economia baseada na agropecuária e agroindústria. Os solos são usados principalmente para pastagens e plantações de café, milho e laranja. Nos últimos anos tem se verificado sensível desenvolvimento industrial em pólos regionais como Pouso Alegre, Varginha, Itajubá e Santa Rita do Sapucaí. As principais sedes municipais das bacias estudadas são Pouso Alegre (bacia do rio Mandu), Congonhal (bacia do rio do Cervo) e Heliodora (bacia do rio Turvo).

A porção sul de Minas Gerais insere-se no domínio do Escudo Atlântico Brasileiro, compartimento geoestrutural da Província Mantiqueira (Almeida, 1981). As rochas arqueanas apresentam-se cortadas por extensos falhamentos brasilianos associados a cinturões de cisalhamento. Predominam gnaisses e migmatitos do Complexo Varginha, do Complexo Amparo, e do Grupo Andrelândia (COMIG, 1994). O contato entre as unidades é realizado pelos citados falhamentos compressivos transcorrentes e inversos de direções predominantes NNE-SSW e ENE-WSW, coincidindo com trecho da denominada "Descontinuidade Crustal do Alto Rio Grande" (Saadi, 1991)

Dentre os resultados dos estudos realizados na região, desde meados deste século (Moraes Rego, 1932; Martonne, 1940; Ruellan, 1953; King, 1956; Ab'Saber e Bernardes, 1958; Almeida, 1964), destaca-se um relativo consenso sobre o forte condicionamento tectônicoestrutural da evolução e da configuração geomorfológica quaternária. As movimentações do Sistema de Rifts da Serra do Mar (Almeida, 1964) e da Faixa Mantiqueira vêm propagando seus efeitos para o interior do continente, até mesmo durante o Quaternário, por meio de uma "tectônica residual" (Saadi, op. cit.). Os efeitos envolvem o escalonamento do relevo em degraus basculados para NW e reativações de grandes falhas brasilianas presentes em zonas de cisalhamento como a Zona Rúptil Carandaí-Mogi Guaçu (Wernick et al, 1981; Artur e Wernick, 1993), também conhecida como Zona de Cisalhamento Ouro Fino (Cavalcante et al., 1979).

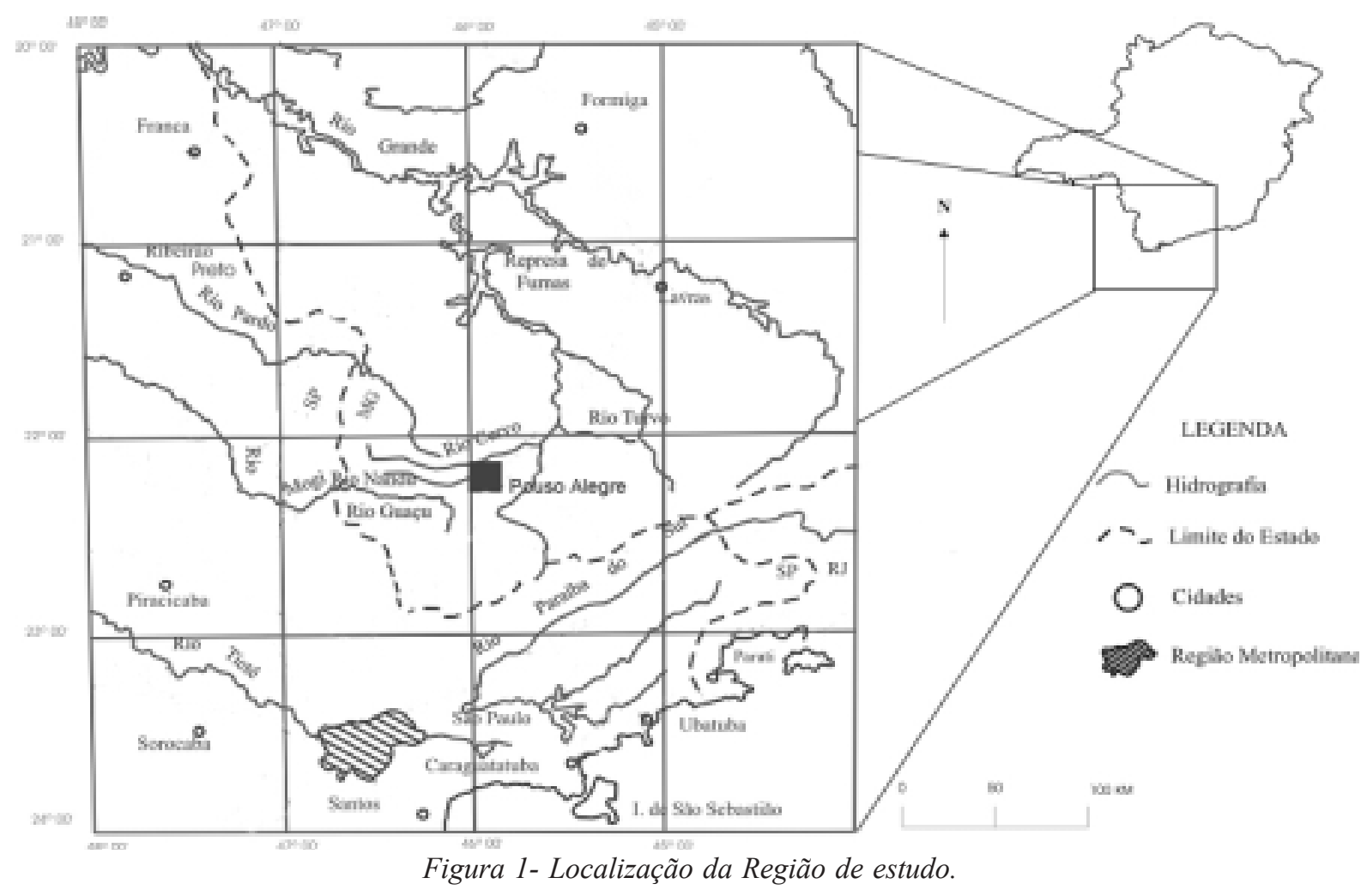


A região sul de Minas Gerais situa-se, portanto, em um contexto geológico peculiar, de caráter transicional (Fig. 2):

a) entre a borda sul do Cráton do São Francisco e o sistema Serra da Mantiqueira, uma faixa móvel brasiliana de direção geral NE-SW, reativada no Cenozóico.

b) entre a Zona Rúptil Carandaí-Mogi Guaçu (NESW), e as Cunhas Tectônicas de Socorro (Cavalcante et al, op. cit.), a SE da região, e de Guaxupé, a NW, dois blocos rígidos relativamente estabilizados ao longo do Cenozóico (Hasui et al., 1984).

O termo "cunha tectônica" é aqui utilizado no sentido de bloco tectônico alóctone, como proposto por Wernick et al. (1981), enfatizando sua conotação genética de blocos deslocados no Ciclo Brasiliano. Campos Neto (2000) refere-se às cunhas como um único domínio denominado "The upper high-temperature Socorro-Guaxupé Nappe", o qual seria um extenso bloco crustal alóctone de pelo menos $10 \mathrm{Km}$ de espessura.

Os contatos entre blocos tectônicos refletem-se na configuração da rede de drenagem da bacia do rio Sapucaí, a qual apresenta quatro conjuntos de orientações preferenciais:

1)NNE-SSW: predomina nos canais de $1^{\mathrm{a}}$ e $2^{\mathrm{a}}$ ordens, principalmente na porção NW da bacia do Sapucaí (sub-bacias dos rios do Cervo e Mandu).

2) $N N W$-SSE: predomina nos canais de $1^{\mathrm{a}} \mathrm{e} 2^{\mathrm{a}}$ ordens nas sub-bacias situadas a N/NE da região: rios Dourado, Lourenço Velho e Turvo.

3) NE-SW: predomina nos canais de $3^{\mathrm{a}}$ e $4^{\mathrm{a}}$ ordens, com destaque para as bacias dos rios Dourado, Lourenço Velho, Mandu e Sapucaí Mirim.

4) $E N E-W S W$ : predomina nos canais de $3^{\mathrm{a}} \mathrm{e} 4^{\mathrm{a}}$ ordens, principalmente a $\mathrm{N}$ (sub-bacias dos rios do Cervo e Dourado).
Os sistemas estruturais brasilianos de direção NNESSW e NNW-SSE condicionam preferencialmente canais de ordem inferior $\left(1^{\mathrm{a}}\right.$ e $\left.2^{\mathrm{a}}\right)$, enquanto o controle das estruturas NE-SW e ENE-WSW está mais presente nos canais de $3^{\mathrm{a}}$ e $4^{\mathrm{a}}$ ordens.

As redes fluviais NE-SW e os sistemas derivados (NNE-SSW e ENE-WSW) devem sofrer condicionamento direto das zonas rúpteis associadas ao "Sistema de Rifts da Serra do Mar" (Almeida, 1976), cujos reflexos rumo ao interior do continente podem ter originado zonas de cisalhamento de menor extensão. Quanto à direção NW-SE, esta corresponde às estruturas geradas no Ciclo Uruçuano e reativadas sucessivamente até o fim do Ciclo Brasiliano (Braun e Baptista, 1977). Esta direção pode refletir as influências topográficas do reconhecido basculamento regional para NW (King, 1956).

A maior parte dos vales de afluentes do rio Sapucaí estão escavados, parcial ou totalmente, nos eixos de falhamentos transcorrentes regionais, como por exemplo:

- Vale do rio do Cervo - eixo da Falha de Jacutinga, com direção WSW - ENE ("Cinturão de Cisalhamento Ouro Fino").

- Vale do rio Turvo - eixo das Falhas de Jacutinga e Borda da Mata, com direção geral WSW-ENE ("Cinturão de Cisalhamento Ouro Fino").

- Vale do rio Mandu - eixo das Falhas de Borda da Mata e Monte Sião, com direção WSW-ENE ("Cinturão de Cisalhamento Ouro Fino").

- Vale do rio Itaim - eixo da Falha de Extrema, com direção SSW-NNE ("Cinturão de Cisalhamento Camanducaia").

- Vale do rio Lourenço Velho - eixo da Falha de Lourenço Velho, de direção WNW-ESE (transversal ao "Sistema de Falhas Serra da Mantiqueira").

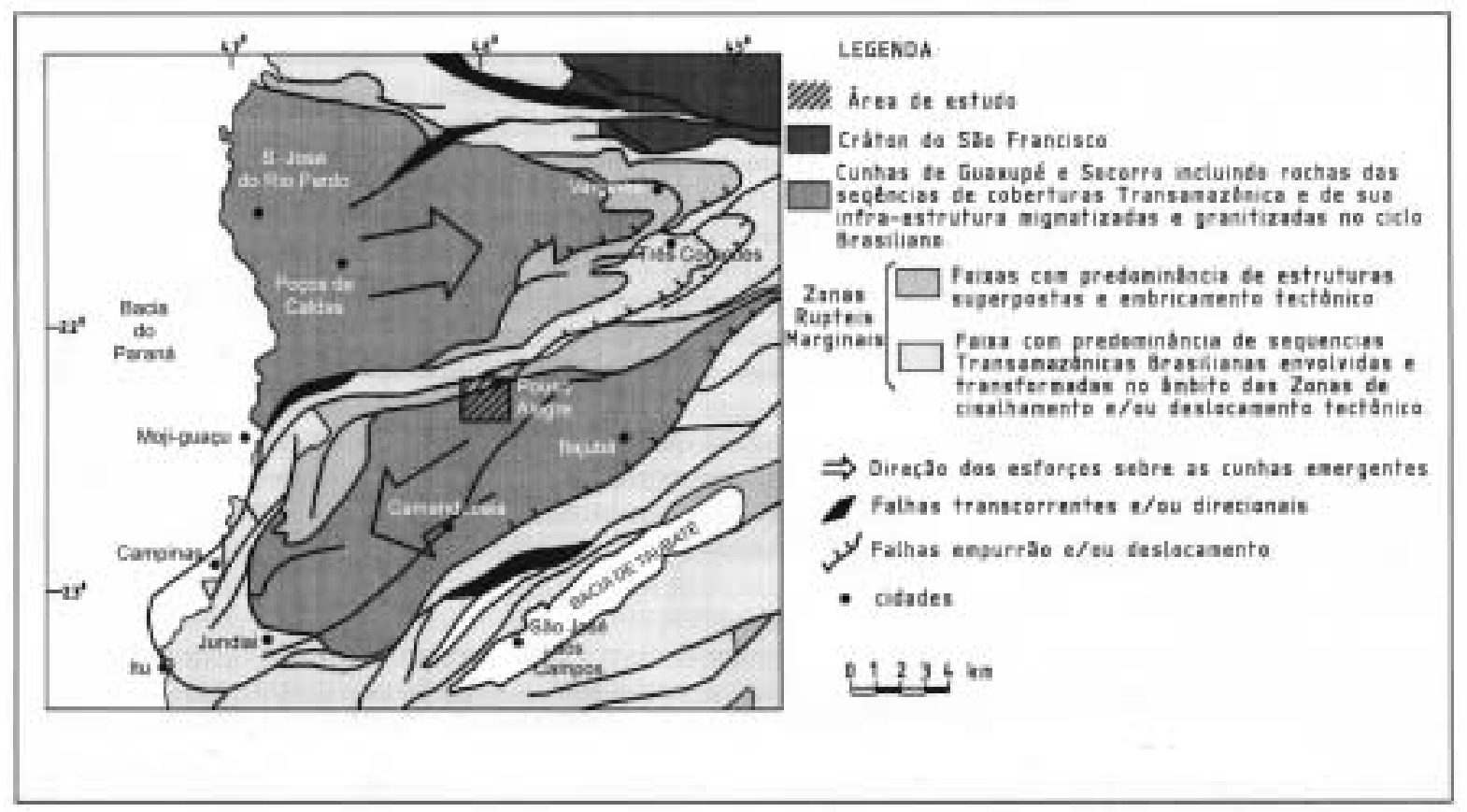

Figura 2- Mapa Geológico da Região de estudo. 
Além dos reflexos nas direções e padrões de drenagem, o controle estrutural extende-se à presença de cortes epigênicos em serras de direção NE-SW, e a extensos trechos fluviais entulhados, inclusive no próprio rio Sapucaí, coincidindo geralmente com zonas limitadas ou cortadas pelas grandes falhas regionais NE-SW.

Possuindo como unidade morfológica cimeira a Serra da Mantiqueira, o sul de Minas Gerais situa-se no domínio dos denominados Planaltos do Sul de Minas (IBGE, 1977), marcados por uma seqüência de compartimentos de colinas interrompidas por serras de direção preferencial NE-SW, coincidentes com os falhamentos transcorrentes brasilianos. O modelado configura-se por meio de compartimentos morfológicos distribuídos em planaltos escalonados ("degraus") a partir da Serra da Mantiqueira, estando basculados para NW em função das reativações cenozóicas das faixas móveis da borda oriental do SE do país.

\section{CARACTERIZAÇÃOGEOMORFOLÓGICADAS BACIAS}

\section{Bacia do Rio do Cervo}

A bacia do rio do Cervo está situada em trecho da Zona Rúptil Carandaí-Mogi Guaçu, apresentando direção geral WSW-ENE e área aproximada de 1.123 $\mathrm{km}^{2}$. As principais unidades litológicas são os granitos e migmatitos pré-Cambrianos do Complexo Varginha, os quais sustentam a Serra do Cervo ao longo de quase toda a margem esquerda do rio do Cervo, e as rochas gnáissicas do Complexo Itapira, na margem direita. Todas as rochas pertencem à Associação Barbacena de Cavalcante et al (1979), tendo sido remobilizadas no Ciclo Brasiliano e recobertas por formações coluviais e aluviais cenozóicas.

Dentre os planaltos escalonados e basculados para NW a partir da Serra da Mantiqueira, o denominado Degrau Intermediário (Saadi, 1991) abrange o vale do rio do Cervo, estando marcado pela influência das zonas de cisalhamento responsáveis pelo "fatiamento" do relevo em diversas cristas de direção ENE-NE. O rio do Cervo tem seu curso inserido, em grande parte, na base da Serra do Cervo, a unidade morfológica cimeira da bacia.

A análise geomorfológica revelou quatro conjuntos morfoestruturaiscondicionadospelossistemasestuturaisNNE-WSW (paralelosaoriodoCervo), “'atiando"orelevoaolongodosfallhamentos:

1) Serra do Cervo: unidade cimeira com morfodinâmica instável no Cenozóico. Situa-se na margem esquerda do rio homônimo, com altitudes médias entre 1300 e $1500 \mathrm{~m} \mathrm{e}$ direção geral ENE-WSW;

2) Baixos Terraços e Várzea: extensa zona deposicional suavizada, na qual se instala o rio do Cervo, com altitudes médias entre 800 e $840 \mathrm{~m}$;

3) Domínio de Morros e Colinas: situado na margem direita do vale principal, a cerca de 840-900 m de altitude, apresenta morfodinâmica relativamente estável;
4) Domínio de Cristas Meridionais: situado na borda sul da bacia, com formas de direção geral NE-SW e altitudes médias entre 1100 e $1300 \mathrm{~m}$.

Apesar da Bacia apresentar diferenciações geomorfológicas longitudinais ao vale principal (direção NE-SW), a compartimentação é fundamentalmente transversal (direção N-S). Aspectos como morfologia, padrões e direções de drenagem variam significativamente entre as duas margens do coletor principal.

A maior instabilidade morfodinâmica verificada na margem esquerda, fato atestado pela ocorrência de queda de blocos, cicatrizes de deslizamentos, capturas fluviais e forte dissecação da morfologia, está correlacionada com o elevado controle tectônicoestrutural, principalmente de lineamentos NE-SW e NWSE. Neste caso, a morfodinâmica cenozóica tem sido influenciada pelos eventos responsáveis por soerguimentos da Serra do Cervo e pela geração do "Graben do rio do Cervo", no qual se instala a calha do rio homônimo (Magalhães e Trindade, 1996). Esta estrutura é, na realidade, um hemi-graben gerado como conseqüência dos soerguimentos da Serra, levando a fortes tensões na zona de contato rígida com o bloco tectônico adjacente a SE. Os efeitos distensivos na base da Serra, associados ao basculamento do citado bloco (reprodução do comportamento tectônico regional do Sistema Mantiqueira), tem levado à evolução policíclica do hemi-graben, o qual "capturou" o nível de base local (rio do Cervo)levando à sua migração lateral de SE para NW.

Foi verificado que as mais claras evidências de controle estrutural sobre a morfologia e morfodinâmica predominam na margem esquerda do vale, e em trecho da margem direita no alto curso do rio do Cervo, onde o condicionamento é atestado principalmente pela morfologia, pelo padrão de drenagem (padrão paralelo) e pela relativa abundância de evidências de capturas fluviais. Esta região também abrange as cabeceiras do vale do rio Mandu, a sul. Com direção semelhante ao rio do Cervo, o rio Mandu também apresenta maior instabilidade no alto curso. Os estudos revelaram semelhanças entre a dinâmica fluvial quaternária nas duas bacias.

\section{Níveis e Seqüências Estratigráficas}

São encontrados quatro níveis deposicionais aluviais na bacia do rio do Cervo, sendo três níveis de terraços escalonados e um nível de várzea parcialmente embutido no terraço inferior (Magalhães e Trindade, 1996; 1997). Foram elaboradas seções-síntese ilustrativas das seqüências estratigráficas dos níveis aluviais, já que são as mais desenvolvidas da área estudada (Fig. 3).

As alturas em relação ao nível de base variam ao longo dos segmentos (Fig. 4). As altitudes médias dos níveis deposicionais variam entre 810 e $920 \mathrm{~m}$.

a) Terraço Superior - T3

Apresenta nível basal de seixos de quartzo suportados, recoberto por material argilo-arenoso 
maciço, marrom amarelado a marrom avermelhado. Os percentuais de finos (argila/silte) e de argila são de $60 \mathrm{e}$ $50 \%$ respectivamente. Há um baixo percentual de matéria orgânica: 0,57 \%.

b) Terraço Intermediário - T2

Assemelha-se ao T3, apresentando nível basal de seixos de quartzo suportados, recobertos por material argiloso, maciço, marrom amarelado a avermelhado. Percentuais de 60 a $71 \%$ de finos foram encontrados, dos quais 50 a $52 \%$ são de argila. O conteúdo de matéria orgânica é baixo: 0,89 a 1,59 \%. Assim como no caso do $\mathrm{T} 3$, os remanescentes do T2 encontram-se mais preservados na margem direita do Vale, fato condicionado pela Serra do Cervo na margem esquerda.

c) Terraço Inferior - T1

O terraço mais recente apresenta níveis basais de seixos de quartzo e do embasamento, recobertos por material argiloso na base tendendo a argilo-arenoso ou franco-arenoso em direção ao topo, maciço, marrom, cinza ou preto, rico em matéria orgânica, e com mosqueamentos avermelhados. Nestes materiais de cobertura, foram encontrados percentuais de finos de 51 a $60 \%$ na base, dos quais 40 a $42 \%$ de argila, e $62 \%$ de finos e $39 \%$ de argila na porção superior. Os percentuais de matéria orgânica variam de 0,13 a 6,58 \% no vale do ribeirão Bicas.

d) Nível de Várzea

O perfil-síntese da várzea constitui-se de dois ciclos deposicionais, ambos com nível basal de seixos de quartzo recoberto por areia média a grossa esbranquiçada, e material argilo-arenoso a arenoargiloso marrom acinzentado a preto, rico em matéria orgânica, em meio ao qual aparecem lentes de areia fina a média e mosqueamentos amarelados a avermelhados. São encontradas estruturas plano-paralelas e cruzadas acanaladas tanto nos níveis detríticos como no material mais fino.

Tabela 1 - Níveis Deposicionais Aluviais do rio do

\begin{tabular}{|c|c|c|}
\hline Nível & $\begin{array}{c}\text { Cistribuição } \\
\text { Espacial }\end{array}$ & $\begin{array}{c}\text { Desnível } \\
\text { médio da base } \\
\text { à calha (m) - } \\
\text { do alto para } \\
\text { o baixo curso }\end{array}$ \\
\hline T3 & $\begin{array}{c}\text { Alto e baixo } \\
\text { curso }\end{array}$ & \multicolumn{2}{|c|}{8} \\
\hline T2 & $\begin{array}{c}\text { Alto e baixo } \\
\text { curso }\end{array}$ & 2 a 7 \\
\hline T1 & Todo o curso & 2 a 5 \\
\hline Várzea & Todo o curso & 0,5 a 5 \\
\hline
\end{tabular}

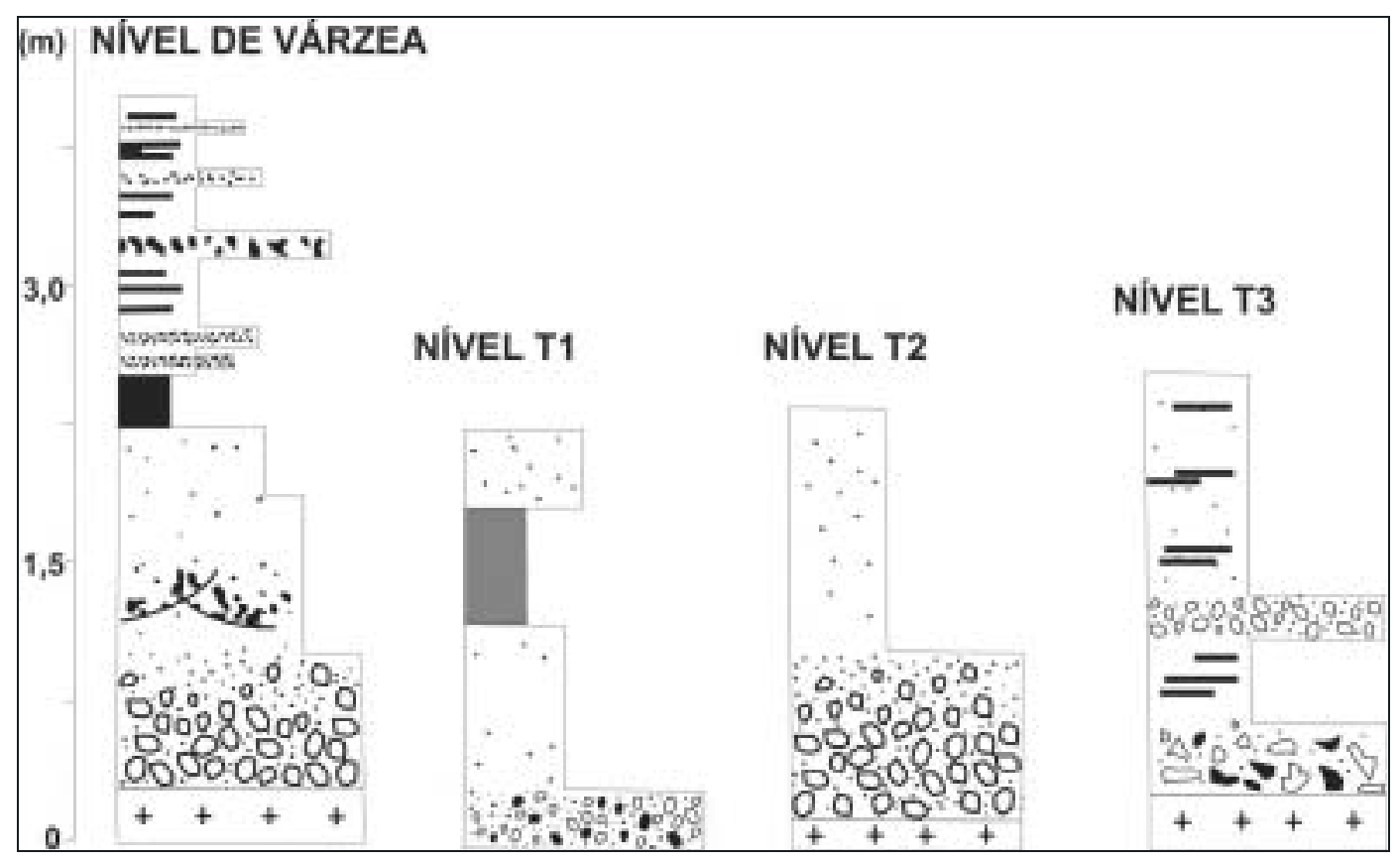

Figura 3 - Seções Estratigráficas-Síntese dos Níveis Aluviais do Rio do Cervo (Obs: As seções do rio do Cervo são as mais representativas da região). 


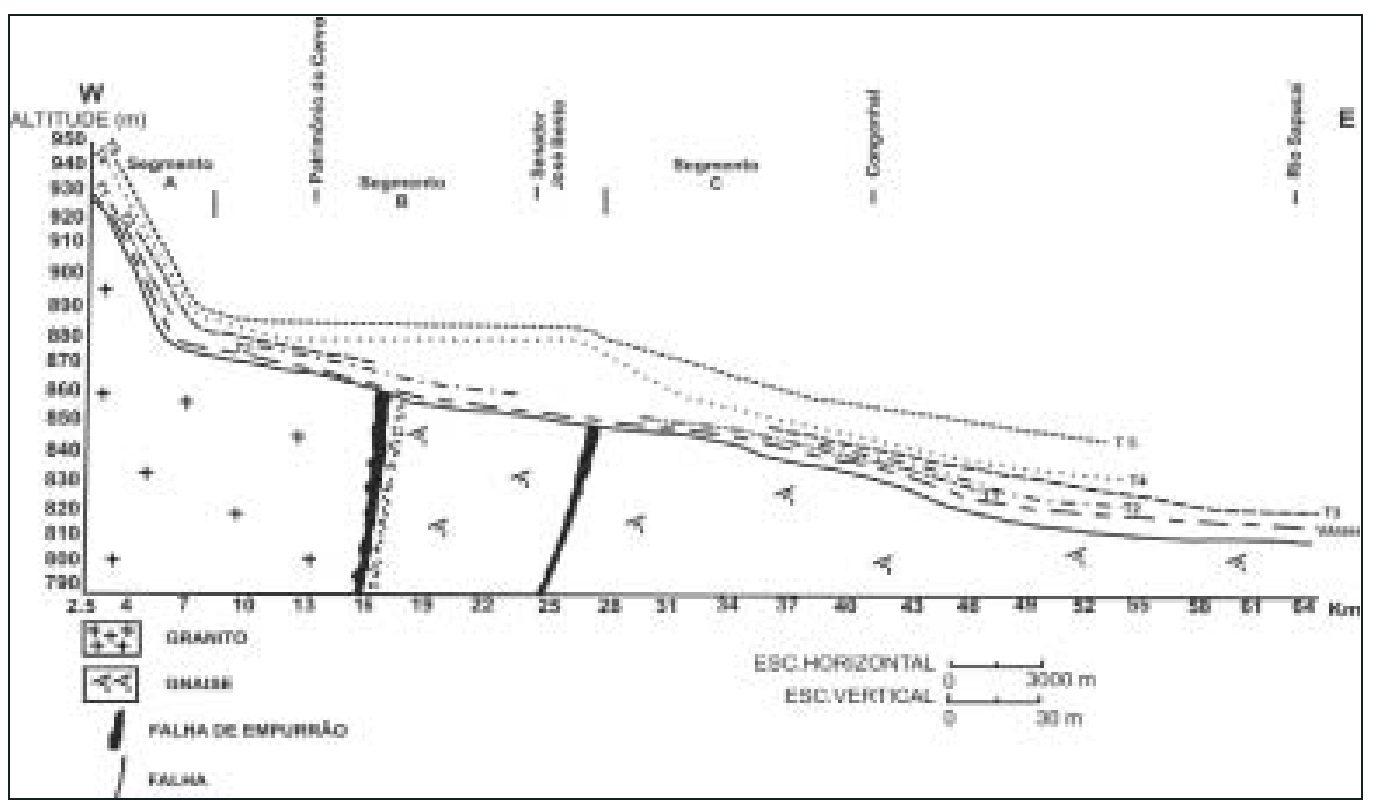

Figura 4 - Perfil Longitudinal do Rio do Cervo e Niveis Aluviais

\section{Bacia do Rio Mandu}

A bacia do rio Mandu possui uma área aproximada de 987 km². O rio Mandu apresenta direção geral W-E, percorrendo cerca de $46 \mathrm{Km}$ até desaguar no rio SapucaíMirim, principal afluente do rio Sapucaí.

$\mathrm{Na}$ porção setentrional da Bacia, correspondendo à margem esquerda do rio Mandu, ocorrem morros e blocos serranos com altitudes entre 820-1340 m. Constituem-se em divisores entre as bacias dos rios Mandu e Cervo. Características peculiares são os ravinamentos profundos e as cicatrizes de deslizamento associadas à incisão de canais fluviais nos amplos anfiteatros erosivos (zonas de cabeceiras).

Um amplo setor suavizado de baixos terraços e várzea do rio Mandu ocorre a altitudes entre $810-920 \mathrm{~m}$. Engloba o médio e baixo curso do rio, bordejado pelos três níveis de terraços identificados. Patamares rebaixados ocorrem no médio e baixo rio Mandu (880$920 \mathrm{~m}$ ), em uma faixa estreita ao longo da margem direita. Constituem-se em interflúvios largos e alongados na direção N-S, com topos aplainados. Estes patamares rebaixados podem representar remanescentes de um nível de erosão fluvial pré-T3. Segundo King (1956), os remanescentes da Superfície Sul-Americana na região situariam-se justamente nesta classe altimétrica.

Ocupando quase toda a margem direita da Bacia, no alto e médio curso do rio Mandu, ocorrem cristas e vertentes orientadas a altitudes médias entre 860-1330 m. Nesta área de forte controle estrutural, predominam serras e interflúvios estreitos e alongados na direção N-S, vertentes abruptas, abundantes ravinamentos, pronunciado recuo de cabeceiras em amplos anfiteatros de erosão e recentes cicatrizes de deslizamento. Não são raras as evidências de capturas fluviais. Sobre os migmatitos e gnaisses da porção ocidental da Bacia, os interflúvios assumem a direção dos falhamentos daZona Rúptil Carandaí-Mogi Guaçu(NE-ENE). Nos limites meridionais do Domínio ocorrem serras que se constituem em divisores entre as bacias dos rios Mandu e Mogi Guaçu, destacando-se as serras da Boa Vista e dos Capitães, com desníveis altimétricos de até $300 \mathrm{~m}$.

Finalmente, destaca-se o "Canyon" do Ribeirão do Pântano (860 - $1490 \mathrm{~m}$ ), afluente da margem direita do rio Mandu. Configura-se em um braço anômalo com cerca de $35 \mathrm{~km}$ de comprimento na direção NNE-SSW, rumo à bacia do rio Mogi Guaçu. $\mathrm{O}$ vale foi esculpido ao longo da Falha de Senador Amaral, apresentando perfil longitudinal com sucessivos degraus topográficos.

Níveis e Seqüencias Deposicionais

Também foram identificados quatro níveis aluviais na bacia do rio Mandu, sendo três terraços escalonados e um nível de várzea parcialmente embutido (Magalhães e Trindade, 1998). Assim como na bacia do rio do Cervo, as altitudes médias dos níveis deposicionais situam-se entre 810 e 920 m. As seções sedimentares são descritas a seguir (do nível mais antigo para o mais recente)

\section{a) Terraço Superior - T3}

Ocorre apenas na margem direita do rio Mandu, estando incorporado ao setor médio das encostas. As seções constituem-se de nível basal de seixos de quartzo suportados, subangulosos, recobertos por areia grossa e material argilo-arenoso marrom-avermelhado com seixos de quartzo esparsos.

\section{b) Terraço Intermediário - T2}

É encontrado na margem direita do rio Mandu e, assim como o T3, não apresenta mais sua configuração original por estar recoberto por uma seqüência coluvial avermelhada. Constitui-se de nível basal de seixos angulosos e subangulosos de quartzo, recoberto por material siltoarenoso marrom amarelado, a argilo-arenoso acinzentado.

c) Terraço Inferior - T1

É encontrado ao longo de todo o vale do rio Mandu e de seus principais afluentes, apresentando grande 
extensão na margem direita. A seção estratigráfica mais representativa foi encontrada no vale do rio Inhumas (afluente do rio Mandu pela margem esquerda), consistindo, da base para o topo, de material argiloarenoso orgânico, nível de seixos angulosos de quartzo em meio a matriz argilo-arenosa, material areno-siltoso marrom amarelado com abundância de grânulos de quartzo e material areno-argiloso marrom com grânulos e seixos de quartzo esparsos.

d) Nível de Várzea

Apresenta grande extensão na margem direita do médio e baixo cursos do rio Mandu, ocorrendo também ao longo dos principais afluentes. Não é possível visualizar o contato entre a base da várzea e a base do T1. A seção-síntese apresenta: nível basal de areia grossa com gradual transição para areia fina, rica em matéria orgânica pouco decomposta; material arenoargiloso a argilo-siltoso acizentado a preto, maciço; areia grossa esbranquiçada; material argilo-arenoso marrom escuro maciço com abundantes lentes de areia grossa. A base da várzea está encoberta pela lâmina d'água.

Tabela 2 - Níveis Deposicionais Aluviais do rio Mandu

\begin{tabular}{|c|c|c|}
\hline Nível & $\begin{array}{c}\text { Distribuição } \\
\text { Espacial }\end{array}$ & $\begin{array}{c}\text { Desnível } \\
\text { médio da base } \\
\text { em relação à } \\
\text { calha (m) }\end{array}$ \\
\hline T3 & Médio curso & 10 \\
\hline T2 & Alto curso & $4-6$ \\
\hline T1 & Todo o curso & - \\
\hline Várzea & Todo o curso & $2-3$ \\
\hline
\end{tabular}

\section{Bacia do Rio Turvo}

O rio Turvo apresenta cerca de $51 \mathrm{~km}$ de extensão e é afluente do rio Sapucaí pela margem direita. A Bacia abrange os municípios de Careaçu, Heliodora, Natércia e Conceição da Pedra, inserindo-se na Zona Rúptil Carandaí-Mogi-Guaçu.

$\mathrm{Na}$ porção meridional da bacia ocorrem morros fortemente dissecados, entre a Serra da Pedra Branca e a Falha de Borda da Mata. As altitudes médias são de $1000 \mathrm{~m}$. A morfologia apresenta-se fortemente dissecada, com vales encaixados e quase ausência de várzeas fluviais.

Entre a porção anterior e a Serra de Santa Catarina ocorre um domínio de morros fortemente dissecados a altitudes médias de $1100 \mathrm{~m}$. Apresentam intensa dinâmica de encostas, com maior freqüência de cicatrizes de deslizamento, anfiteatros e voçorocas. O domínio foi esculpido pelo ribeirão São Bernardo (direção E-W) e seus tributários, sendo ainda cortado pelo rio Turvo na porção W. Neste trecho, o rio Turvo passa a apresentar uma extensa várzea, ao contrário do trecho à montante.

Na porção central da Bacia situa-se a Serra de Santa Catarina, com direção E-W e altitudes médias de 1400 m. A vertente $\mathrm{N}$ constitui a escarpa principal, caracterizada como de empurrão e gerada em função da Falha de Santa Catarina. A Serra representa o divisor de drenagem das Bacias do ribeirão São Bernardo e do ribeirão Santa Izabel, enquanto sua extremidade W é cortada pelo rio Turvo em um vale epigênico, onde sua várzea torna-se abruptamente estreita.

$\mathrm{Na}$ porção $\mathrm{N}$ da Bacia ocorrem colinas de topos arredondados e morros rebaixados e alongados, com altitudes médias de $900 \mathrm{~m}$. A morfodinâmica de encostas é melhor representada por anfiteatros erosivos, principalmente no vale do ribeirão Areado. As várzeas ocorrem extensivamente ao longo dos trechos médio e baixo dos vales do rio Turvo, ribeirão Areado e ribeirão do Ataque.

A Serra das Águas (prolongamento NW da Serra do Cervo) compreende o limite setentrional da Bacia, apresentando direção geral ENE-WSW e altitudes médias de $1150 \mathrm{~m}$. Verifica-se abundância de cristas e vales encaixados, e sua vertente $\mathrm{N}$ ocorre sob forma de uma escarpa de empurrão coincidente com um extenso falhamento inverso da Zona Rúptil Carandaí-Mogi Guaçu.

\section{Níveis e Seqüências Deposicionais}

Foram identificados dois níveis de terraços escalonados e um nível de várzea parcialmente embutido no terraço inferior (Magalhães e Ferreira, 1998).

\section{a) Terraço Superior - T2}

Encontrado em raros pontos dos vales dos rios Turvo e Areado, apresenta seção-síntese formada por nível basal de seixos de quartzo suportados, subarredondados, com tamanho médio de 3 a $4 \mathrm{~cm}$, recoberto por material areno-argiloso marrom a marrom avermelhado. As altitudes variam de $850 \mathrm{~m}$ no vale do rio Turvo, a 840-880 m no vale do rio Areado.

\section{b) Terraço Inferior - $T$}

Com distribuição espacial mais generalizada do que o T2, o T1 é encontrado nos vales do rio Turvo e de seus principais afluentes. Não apresenta seções totalmente expostas devido ao parcial embutimento da várzea. Apresenta material areno-argiloso marrom escuro, rico em matéria orgânica. No vale do córrego Atirado, os depósitos apresentam, certas vezes, textura argilo-arenosa e cor cinza a preto na base, e marrom no topo.

\section{c) Nível de Várzea}

A várzea apresenta dimensões significativas no médio-baixo vale do rio Turvo, e em trechos localizados dos vales dos córregos Areado e Atirado. Os depósitos são de textura areno-argilosa e cor marrom a marrom acinzentado, com espessura média de $3 \mathrm{~m}$. A base encontra-se submersa pela lâmina d'água.

Tabela 3 - Niveis Deposicionais Aluviais do rio

\begin{tabular}{|c|c|c|}
\hline Nível & $\begin{array}{c}\text { Distribuição } \\
\text { Espacial }\end{array}$ & $\begin{array}{c}\text { Desnível } \\
\text { médio da base } \\
\text { em relação à } \\
\text { calha (m) }\end{array}$ \\
\hline T2 & Médio curso & 8 \\
\hline T1 & Todo $~$ & 0,5 \\
\hline Várzea & Todo $\circ$ curso & 0 \\
\hline
\end{tabular}




\section{Formações Superficiais Coluviais e Eluviais}

Foram identificadas seqüências coluviais presentes nas três bacias, sendo mais comum uma seqüência constituída por stone-line basal de seixos angulosos de quartzo e das rochas do embasamento, recoberta por material areno-siltoso marrom avermelhado a amarelado. Em certos casos o material aparece recobrindo os terraços superiores.

Deve-se ainda mencionar a presença local de seqüências eluviais de seixos angulosos a subangulosos de quartzo e principalmente do substrato, geradas "in-situ" através do intemperismo das rochas do embasamento. Análises granulométricas demonstraram pequenas variações entre os materiais superior e inferior ao nível detrítico, em todas as classes texturais. Em certos casos é visível a gênese dos seixos a partir da meteorização interna e fragmentação local dos afloramentos rochosos mais resistentes, preservados do intenso intemperismo, e a total remoção dos caracteres originais da rocha sã. Os seixos subarredondados derivam tão somente da eficaz atuação do intemperismo esferoidal.

A origem "in-situ” também aplica-se a um nível de fragmentos lateríticos embasado e recoberto pelo substrato intemperizado. Eventos tectônicos recentes podem ter sido responsáveis pela total fragmentação da crosta laterítica e deformação do nível detrítico citado acima, cujo arranjo espacial é marcado por fortes ondulações. O rebaixamento do nível d’água subterrâneo deve ter auxiliado a evolução do "front" de intemperismo, homogeneizando o perfil.

\section{RECONSTITUIÇÃO DOS PRINCIPAIS EVENTOS MORFODINÂMICOS CENOZÓICOS}

\section{Bacia do Rio do Cervo}

Na bacia do rio do Cervo o evento morfodinâmico mais antigo registrado corresponde ao T3, mas um ou mais níveis de terraços mais antigos certamente existiram, já que suas evidências estão impressas principalmente em certos topos aplainados e patamares escalonados nas colinas da margem direita do Vale. Encontram-se também seixos arredondados esparsos no colúvio da área, situados a altitudes superiores aos remanescentes do T3.

Não foram realizadas, até o momento, análises e datações para um balizamento cronológico mais preciso dos níveis erosivos regionais, utilizando-se técnicas modernas como AFTA (Traço de Fissão de Apatita). Por sua importância histórica na geomorfologia brasileira, cabe ressaltar algumas comparações com os estudos de King (1956) sobre níveis de aplainamento na porção oriental do Brasil, mesmo sabendo-se da carência de provas científicas para suas afirmações.Segundo o autor, os remanescentes da Superfície Gondwana e Pós-Gondwana estariam preservados atualmente na região a altitudes de 1400$1500 \mathrm{~m}$ e $1000 \mathrm{~m}$, respectivamente. Ao referir-se indiretamente à Serra do Cervo, King relacionou os seus topos mais elevados à Superfície Pós-Gondwana, mas estes devem ser relacionados à Superfície Gondwana (segundo os próprios critérios altimétricos de King para a região), já que situam-se entre 1200 e $1400 \mathrm{~m}$. Seguindo esta lógica, a Superfície Pós-Gondwana estaria preservada em patamares e em topos rebaixados da Serra. Sabe-se que estas superfícies não apresentam reconhecimento consensual, sendo difícil a comprovação de níveis tão antigos. King também correlacionou os topos regionais situados a cerca de $900 \mathrm{~m}$ de altitude, a remanescentes da Superfície SulAmericana, correspondendo aos topos das colinas da margem direita do Vale principal.

O T3 teria sido elaborado no Quaternário, a cerca de $840 \mathrm{~m}$ de altitude, estando preservado apenas na margem direita do baixo vale. A dissecação de um paleonível laterítico explica a presença de fragmentos em meio aos seixos de quartzo. O próprio nível de quartzo foi também desagregado por processos de encosta, resultando nos fragmentos encontrados no pacote coluvial da área, contemporâneo ao T3 ou ao ciclo de dissecação seguinte (o coluvio não recobre os níveis de terraços inferiores). A existência de um antigo nível laterítico, e o elevado percentual de argila nos depósitos superiores (42 \%) são evidências de condições sin-genéticas em ambiente tropical úmido. Em uma região de reconhecida instabilidade tectônica, a quase completa remoção dos vestígios do T3 e dos ciclos deposicionais anteriores não pode estar dissociada do condicionamento tectônico.

O T3 teria sido elaborado no Quaternário, a cerca de $840 \mathrm{~m}$ de altitude, estando preservado apenas na margem direita do baixo vale. A dissecação de um paleonível laterítico explica a presença de fragmentos em meio aos seixos de quartzo. O próprio nível de quartzo foi também desagregado por processos de encosta, resultando nos fragmentos encontrados no pacote coluvial da área, contemporâneo ao T3 ou ao ciclo de dissecação seguinte (o coluvio não recobre os níveis de terraços inferiores). A existência de um antigo nível laterítico, e o elevado percentual de argila nos depósitos superiores (42 \%) são evidências de condições sin-genéticas em ambiente tropical úmido. Em uma região de reconhecida instabilidade tectônica, a quase completa remoção dos vestígios do $\mathrm{T} 3$ e dos ciclos deposicionais anteriores não pode estar dissociada do condicionamento tectônico.

O rebaixamento do nível de base posicionou a calha do rio do Cervo a cotas de cerca de $830 \mathrm{~m}$ no baixo vale. O T2 também é encontrado principalmente na margem direita, e seu arranjo espacial evidencia a recente fase de rápida migração do rio do Cervo rumo a margem esquerda do vale. Assim como no caso do T3, os seixos são exclusivamente de quartzo, atestando as condições tropicais úmidas favoráveis ao intenso intemperismo químico e à homogeneização petrográfica. $\mathrm{O}$ elevado percentual de finos (até $71 \%$ ), e particularmente de argila (até $52 \%$ ) nos depósitos superiores, evidencia condições sin-deposicionais de clima úmido em 
ambiente de várzea.

Uma nova e curta fase holocênica de rebaixamento do nível de base permitiu o posicionamento da calha fluvial no nível T1, situado a cotas aproximadas de 827 $\mathrm{m}$ no baixo vale. Este terraço confunde-se visualmente com o T2 e com a várzea, sendo identificado por critérios estratigráficos. Presença exclusiva de seixos de quartzo, predomínio de argila nos depósitos superiores e abundância de matéria orgânica evidenciam a continuidade das condições ambientais úmidas. A análise do paleoperfil longitudinal fluvial demonstra que o maior desnivelamento do T1 ocorre sobre a Falha do Espírito Santo do Dourado, indicando sua provável influência na fase de rebaixamento do nível de base entre os níveis T2-T1. O controle tectônico ativo da gênese dos baixos terraços resultou também na presença predominante do T1 na margem direita do Vale.

A migração quaternária do Canal rumo à margem esquerda pode ser explicada pela presença do Graben do Rio do Cervo. Sua gênese e atividade estariam associadas a soerguimentos na Serra do Cervo e movimentação de extensos falhamentos transcorrentes de direção ENE-WSW como a Falha de Jacutinga, que coincide com a base da serra. A reativação cenozóica destes falhamentos do sul de Minas Gerais deve ter ocorrido por meio de deslocamentos individuais de blocos, soerguidos a SE e basculados para NW, resultando na orientação de escarpas como a da Serra do Cervo (Saadi, 1991).

Os conseqüentes abatimentos da porção $\mathrm{S}$ da Serra provocariam o basculamento do Vale para NW e a rápida migração do canal, com a formação das extensas superfícies deposicionais na margem direita. Com o "aprisionamento" da calha ao longo do Graben, o considerável fluxo fluvial recebido de montante sob as vigentes condições tropicais úmidas seria dispersado na margem direita do baixo curso, em função da presença da Serra na margem oposta. Exceção é feita no local onde a Falha de Senador José Bento controla o canal próximo da margem direita, permitindo, de forma anômala, a maior extensão da várzea na margem esquerda.

A formação do T1 ao longo da calha principal seria também acompanhada pela sedimentação acelerada ao longo dos afluentes, onde são encontradas evidências do efeito remontante do "represamento". A propagação de ambientes propícios ao entulhamento responderia por seqüências deposicionais com predomínio de finos e abundância de matéria orgânica. Enquanto no T1 do rio do Cervo a matéria orgânica ocorre nos depósitos correlativos dos paleoambientes de planície, concentrando-se principalmente nas comuns seqüências de meandros abandonados, nos vales de alguns afluentes esta acumulou-se intensamente em extensos ambientes de planície com tendência a brejos, com concentrações de até $6,59 \%$.

Um rápido ciclo de encaixamento das calhas fluviais foi seguido pela formação do nível de várzea. A dinâmica migratória do Rio do Cervo resultou na assimetria e escalonamento da várzea, marcada por no mínimo dois níveis topográficos distintos separados por cerca de
0,5 m. Os depósitos finos orgânicos evidenciam típico ambiente de planície com abundância de meandros abandonados.

Assim como os terraços, a várzea também é mais desenvolvida na margem direita do Vale, como conseqüência do citado processo de basculamento. $\mathrm{O}$ desvio do canal tem provocado o abandono gradual das porções superiores da várzea e a formação de diversas gerações de meandros abandonados na margem direita. As influências estruturais atuais são nitidamente visualizadas em seções do médio vale onde o nível basal de seixos da várzea encontra-se acima do nível da água, fato devido ao brusco desnivelamento do perfil fluvial condicionado pela falha local. Depósitos superiores ao T1, cortados por falha normal, constituem claras evidências do atual controle tectônico da dinâmica fluvial do Vale.

\section{Bacia do Rio Mandu}

Apesar da ausência de registros sedimentares, o nível erosivo mais antigo identificado topograficamente na Bacia do rio Mandu corresponde aos topos aplainados dos interflúvios do Domínio dos Patamares Rebaixados do Baixo rio Mandu, a altitudes médias entre 900 e $920 \mathrm{~m}$. As seqüências dos níveis deposicionais encontrados indicam condições sindeposicionais em ambiente fluvial meandrante, típico de clima úmido. Os terraços apresentam depósitos de leito na base recobertos por depósitos de barras de pontal e planície. O predomínio de finos e a abundância de matéria orgânica são verificados mais acentuadamente em seqüências pontuais do T2, do T1 e da várzea, em ambientes de meandros abandonados por chutte cut-off e neck cut-off.

Os ciclos de encaixamento fluvial nos períodos pósT3 e pós-T2 permitiram o rebaixamento da calha fluvial de cerca de 9 e $3 \mathrm{~m}$ respectivamente. $\mathrm{O}$ encaixamento nestes ciclos, bem como no ciclo pós-T1, foi acompanhado da acentuada migração lateral do canal rumo à margem esquerda, em direção geral NW, ou seja, rumo ao limite meridional do Domínio dos Morros e Conjuntos Serranos da Margem Esquerda. Este domínio é marcado por interflúvios de direção geral NE-SW, sendo seu limite marcado pela falha de Borda da Mata. A morfologia e o arranjo espacial dos níveis deposicionais demonstra um basculamento do vale do rio Mandu para NW a partir do nível T3, fato que controlou a rápida migração da calha fluvial. Este processo resultou na maior expressão dos níveis de terraços e da várzea na margem direita e na origem de várias gerações de meandros abandonados.

As evidências indicam uma gradual desaceleração ou encurtamento dos ciclos de encaixamento ao longo do tempo, fato que deve estar associado à dinâmica da tectônica regional: atenuação tectônica ou pulsos de instabilidade mais rápidos. $\mathrm{O}$ parcial embutimento da várzea no $\mathrm{T} 1$ deve ter sido condicionado pela elevação do nível de base em função dos efeitos remontantes dos intensos ciclos de entulhamento no rio Sapucaí. Falhas reativadas da Zona Rúptil Carandaí-Mogi Guaçu 
devem atuar como soleiras estruturais na bacia, controlando o processo de entulhamento dos vales no Quaternário. O próprio rio Mandu começa a entulhar somente após "vencer" a resistência das falhas de Ouro Fino e Borda da Mata. As falhas determinam pontos de "estrangulamento" e abertura dos vales, bem como condicionam os vales profundamente encaixados de certos afluentes do rio Mandu, como o ribeirão do Pântano que flui ao longo da Falha de Senador Amaral. A propagação dos efeitos do entulhamento no vale do rio Mandu provocou a formação de ambientes brejosos nos vales dos principais afluentes, gerando aluviões ricos em finos e matéria orgânica.

\section{Bacia do Rio Turvo}

A identificação de poucos níveis deposicionais e sua pequena distribuição espacial denotam o atual estágio de dissecação na Bacia. O nível de terraço mais antigo apresenta forte desnivelamento em sua distribuição longitudinal no vale principal (40 m em 5 $\mathrm{km}$ ). Os depósitos são de ambientes de leito fluvial recobertos por depósitos de barras de pontal e várzea (material areno-argiloso). No vale do rio Turvo, o T2 é encontrado apenas na confluência com o ribeirão São Bernardo, a cerca de $850 \mathrm{~m}$ de altitude. Os depósitos estão deformados, apresentando ondulações no nível detrítico basal.

Assim como verificado nos vales dos rios do Cervo e Mandu, a geração do T1 e da várzea no vale do rio Turvo foi acompanhada pela rápida migração lateral do canal, neste caso rumo à base da Serra das Águas. Como resultado, o T1 tem presença espacial significativa na margem esquerda (não é encontrado na margem direita). No vale do rio Areado o encaixamento atingiu cerca de 20 m (desnível T2-T1). Em vales de alguns afluentes, como no vale do córrego Atirado, o T1 apresenta depósitos finos orgânicos típicos de ambientes brejosos. Como já dito nas outras bacias, estas condições de baixa energia podem refletir o efeito remontante do represamento exercido pelo entulhamento dos fundos de vale dos níveis de base locais.

As condições favoráveis à rápida migração dos canais, têm condicionado a ação conjunta entre a dissecação do leito e margens, resultando no gradual abandono das porções superiores do nível de várzea. Apesar da fácil visualização de meandros abandonados nas várzeas do rio Turvo e do ribeirão Areado, não foram identificados depósitos sin-deposicionais típicos.

A distribuição espacial da várzea do rio Turvo demonstra que a calha fluvial, no médio curso, tem migrado para NE resultando em uma várzea bem mais larga na margem esquerda. No baixo vale, após brusca inflexão do canal para SW, a várzea também é mais significativa na margem esquerda devido à rápida migração da calha para NW, rumo à base da Serra das Águas. A distribuição espacial da várzea e do T1 demonstra que sua gênese está fortemente relacionada ao controle tectônico-estrutural exercido pelos sistemas de falhas da Zona Rúptil Carandaí-Mogi Guaçu.

\section{A TECTÔNICA DIFERENCIAL DE BLOCOSEO CONDICIONAMENTODA DINÂMICA FLUVIAL REGIONAL}

Os eventos neotectônicos originados nas faixas móveis dos sistemas Serra da Mantiqueira e Serra do Mar têm reconhecida origem no contínuo processo de abertura do Atlântico Sul. Estes eventos têm condicionado a reativação de estruturas brasilianas nos Planaltos do Sul de Minas e têm controlado a dinâmica fluvial regional. Os ciclos de acelerada deposição nas bacias estudadas devem ser considerados neste contexto regional, onde extensas falhas transcorrentes associadas a zonas de cisalhamento (faixas móveis) parecem ter condicionado os intensos ciclos de entulhamento recente no médio-baixo curso do rio Sapucaí, com efeitos remontantes ao longo de afluentes.

A dinâmica fluvial cenozóica nas bacias estudadas deve ser analisada no contexto desta posição tectonicamente estratégica da região, marcada por reativações neocenozóicas da Zona Rúptil CarandaíMogi Guaçu, cujas falhas compressivas transcorrentes com direção principal NE-SW, vêm sendo reativadas até o Holoceno. Estas falhas são responsáveis pela fragmentação do relevo e pela direção de várias serras regionais, cujas cristas dissimétricas refletem o basculamento de blocos locais para NW. A região também é cortada pela extensa descontinuidade crustal Itutinga-São Gonçalo do Sapucaí, cujos eixos de tensões mostram compressão NNW-SSE e extensão SW-NE, com caráter transcorrente (Saadi, 1991).

Os sistemas de falhas também respondem por fortes desnivelamentos fluviais, como no médio vale do rio do Cervo onde a Falha de Senador José Bento condiciona a ruptura do perfil fluvial longitudinal desde o ciclo deposicional do Terraço Inferior (T1). O quadro estrutural condiciona a existência de padrões fluviais paralelos com direção predominante NW-SE e a ocorrência do padrão pinado em zonas de falhas como a do Espírito Santo do Dourado e a de Senador José Bento, de direção NE-SW.

O basculamento para NW dos vales principais está associado à presença de blocos serranos de direção NE-SW. Este aspecto confirma os resultados de estudos anteriores que também propuseram o basculamento de morfoestruturas regionais (Martonne,1940; King,1956; Saadi 1991). O vale do rio do Cervo ilustra este fato, estando situado em um planalto inclinado para NW, entre altitudes de $2000 \mathrm{~m}$ na Serra da Mantiqueira e 900 $\mathrm{m}$ na base da Serra do Cervo.

As influências tectônicas regionais sobre a morfodinâmica cenozóica podem ser compreendidas, portanto, a partir do efeito conjunto de três vetores de movimentação:

a) O lento e contínuo soerguimento epirogenético regional, cujos pulsos seriam responsáveis por ciclos de rebaixamento dos níveis de base e geração de terraços escalonados. Neste contexto se inserem as "cunhas tectônicas" estabilizadas e limitadas por faixas móveis. 
b) Soerguimento diferencial e basculamento de blocos, principalmente blocos serranos de direção NESW, como efeito da reativação de faixas móveis. A ausência de depósitos aluviais e a presença de depósitos coluviais detríticos, incluindo fragmentos de laterita, evidenciam intensa dinâmica de encostas nestes blocos. Assim como em alguns domínios morfológicos mais estáveis sob soerguimento, são encontrados paleoravinamentos preenchidos por materiais coluviais típicos de transporte por enxurradas.

c) Subsidência de blocos e geração de hemi-grabens ao longo das faixas móveis, como resultado de esforços distensivos na base dos blocos serranos sob soerguimento espasmódico. Os efeitos destes deslocamentos têm deslocado depósitos orgânicos holocênicos, como verificado no T1 do rio do Cervo (presença de falha normal N60E).

Os reflexos morfotectônicos desta dinâmica diferencial de blocos pode ser melhor compreendida a partir da Figura 5.

A geração dos grabens ao longo da Zona Rúptil Carandaí-Mogi Guaçu enquadra-se no modelo genético tipo "tilt blocks/half grabens" (Leeder \& Gawthorpe, 1989, Mack \& Seager, 1990), no qual bacias subsidentes assimétricas (hanging wall) são geradas como resultado do soerguimento rotacional de blocos (footwall). À medida que o bloco subsidente separa-se do bloco soerguido por esforços extensionais, uma bacia assimétrica é formada e é preenchida por sedimentos (Fig. 6). Neste modelo, Leeder \& Gawthorpe (1989)citam diversos exemplos como os grabens do baixo rio Reno e os grabens do Rift do Rio Grande e do Rio Madison, nos EUA.

No vale do rio do Cervo, o controle tectônico da dinâmica fluvial quaternária, refletindo as reativações da Zona Rúptil Carandaí-Mogi Guaçu, levaram, em grande parte, à remoção quase completa dos registros sedimentares mais antigos ao T3. A acelerada morfodinâmica refletiu-se na preservação de níveis aluviais apenas em situação de meia encosta e fundos de vales.

A distribuição espacial dos níveis deposicionais evidenciam a rápida migração quaternária do rio do Cervo rumo à base da Serra do Cervo, indicando os efeitos dos abatimentos relacionados ao Graben do Rio do Cervo. O "aprisionamento" da calha na margem esquerda e o basculamento do vale para NW seriam acompanhados da gênese de várias gerações de meandros abandonados, do mergulho das camadas fluviais do T2 para NW, do gradual abandono das porções superiores da várzea e do acelerado entulhamento na margem direita, propiciando condições crescentes (do T3 à várzea) de marcante acúmulo de matéria orgânica na planície. Nos vales dos afluentes principais, as planícies por vezes adquiriram nos ciclos mais recentes (T1 e várzea) caráter brejoso, refletindo os efeitos remontantes do entulhamento no nível de base. As análises de difração de raios X das argilas não demonstraram condições climáticas diferentes das atuais.
$\mathrm{Na}$ bacia do rio Mandu, os resultados permitem interpretar a dinâmica fluvial quaternária como fortemente controlada pela atividade dos dois domínios tectônicos principais: Zona Rúptil Carandaí-Mogi Guaçu e Cunha Tectônica de Socorro. A configuração geomorfológica atual da bacia resulta da ação conjunta dos seguintes eventos ao longo do Quaternário:

\section{- Soerguimento da Cunha Tectônica de Socorro}

A borda setentrional deste bloco, morfologicamente representada pela Serra dos Capitães, abrange a porção sul da bacia, sendo um bloco soerguido com destacados desníveis altimétricos em relação aos blocos adjacentes. Seu soerguimento no Cenozóico, aproveitando-se dos falhamentos pré-cambrianos, provocou uma marcante reestruturação da rede fluvial condicionando capturas. Pela configuração espacial da drenagem, os soerguimentos devem ter provocado um redirecionamento dos antigos afluentes meridionais do rio Mandu, impedidos de correr para $\mathrm{N}$ e desviados para E. Um destes afluentes deve ter sido o rio Mogi Guaçu, cujo curso atual acompanha a borda do bloco soerguido, na divisa com a bacia do rio Mandu. Seu curso apresenta nítida inflexão, passando de trecho inicial de direção SE-NW para quase E-W acompanhando o limite do bloco e reforçando a hipótese do redirecionamento imposto. O único afluente a manter seu curso foi o Ribeirão do Pântano, devido ao seu posicionamento na Falha de Senador Amaral, resultando na atual configuração anômala da bacia.

A reativação desta falha condicionou a abertura de um vale epigênico no alto-médio curso do Rio, sendo antecedente à atual configuração morfoestrutural. $\mathrm{O}$ Vale apresenta acentuados desníveis altimétricos, passando de $1400 \mathrm{~m}$ nas cabeceiras, para cerca de $800 \mathrm{~m}$ no baixo curso, à semelhança de um "canyon". O soerguimento do bloco vem provocando um acentuado recuo das cabeceiras na borda meridional da Bacia e uma profunda incisão de canais fluviais no interior de anfiteatros erosivos, como forma de ajustes às novas condições de energia. Neste caso, os cursos d'água principais da bacia do rio Mandu tendem a capturar os afluentes do alto Mogi Guaçu, já que este corre em nível topográfico mais elevado. O soerguimento da Cunha de Socorro foi determinante para a configuração do Domínio das Cristas e Vertentes Orientadas da Margem Direita, marcado por elevado controle estrutural.

- Soerguimento da Serra do Descalvado

A serra insere-se na Zona Rúptil Carandaí-Mogi Guaçu, Domínio dos Morros e Conjuntos Serranos da Margem Esquerda, correspondendo a uma zona cataclástica soerguida ao longo da falha de Monte Sião (seu limite meridional). Com cerca de $1100 \mathrm{~m}$ de altitude, apresenta desníveis de até $200 \mathrm{~m}$ para o rio Mandu.

\section{- Formação do "Graben do Rio Mandu"}

A reativação de falhas da Zona Rúptil CarandaíMogi Guaçu, com o soerguimento da Serra do Descalvado, gerou esforços distensivos que originaram o Graben do Rio Mandu, com eixo na Falha de Monte Sião, na qual se instala a calha do Rio. Os abatimentos provocaram a migração do talvegue rumo à margem 


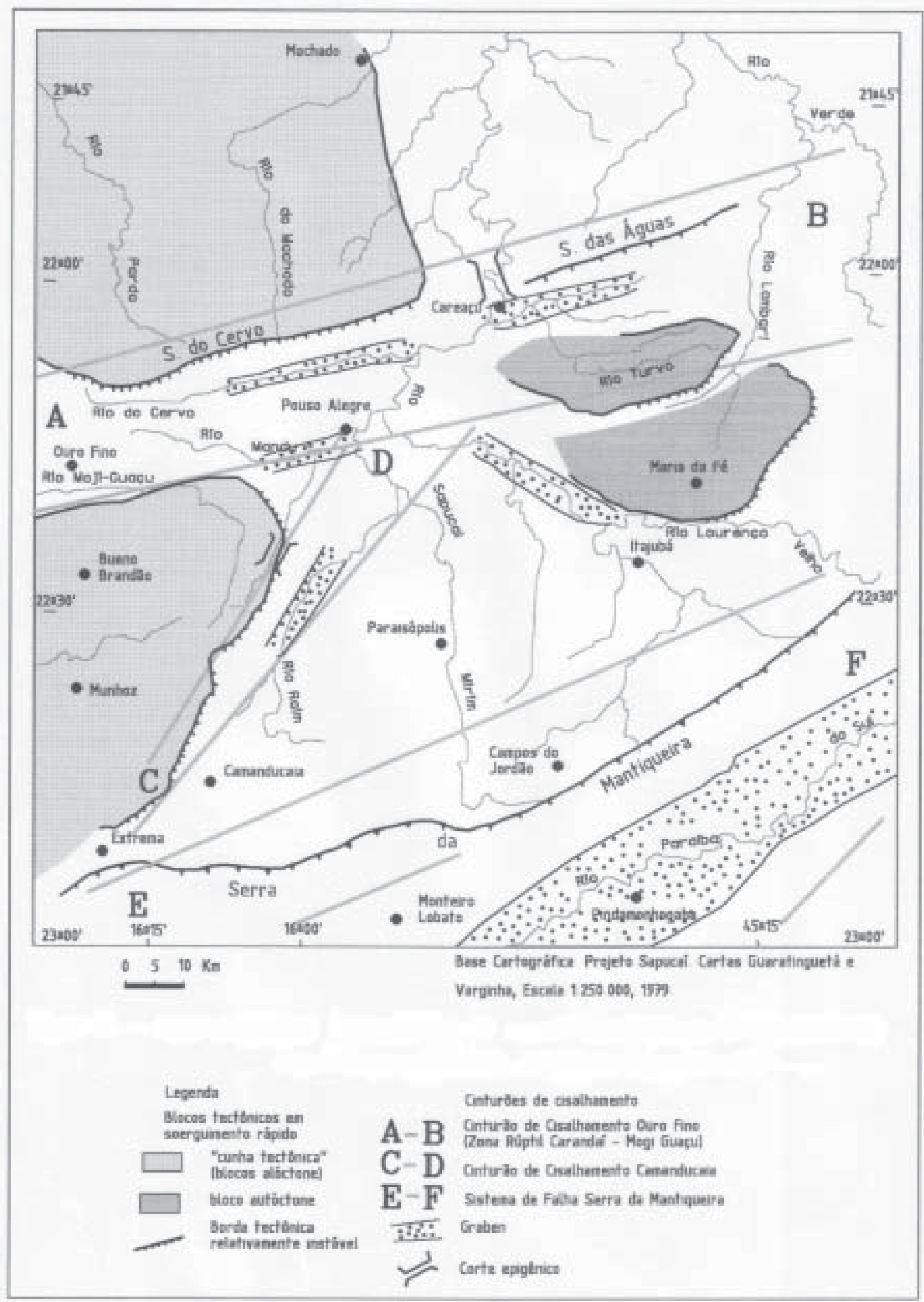

Figura 5 - Compartimentação Morfoestrutural da Bacia do rio Sapucaí 


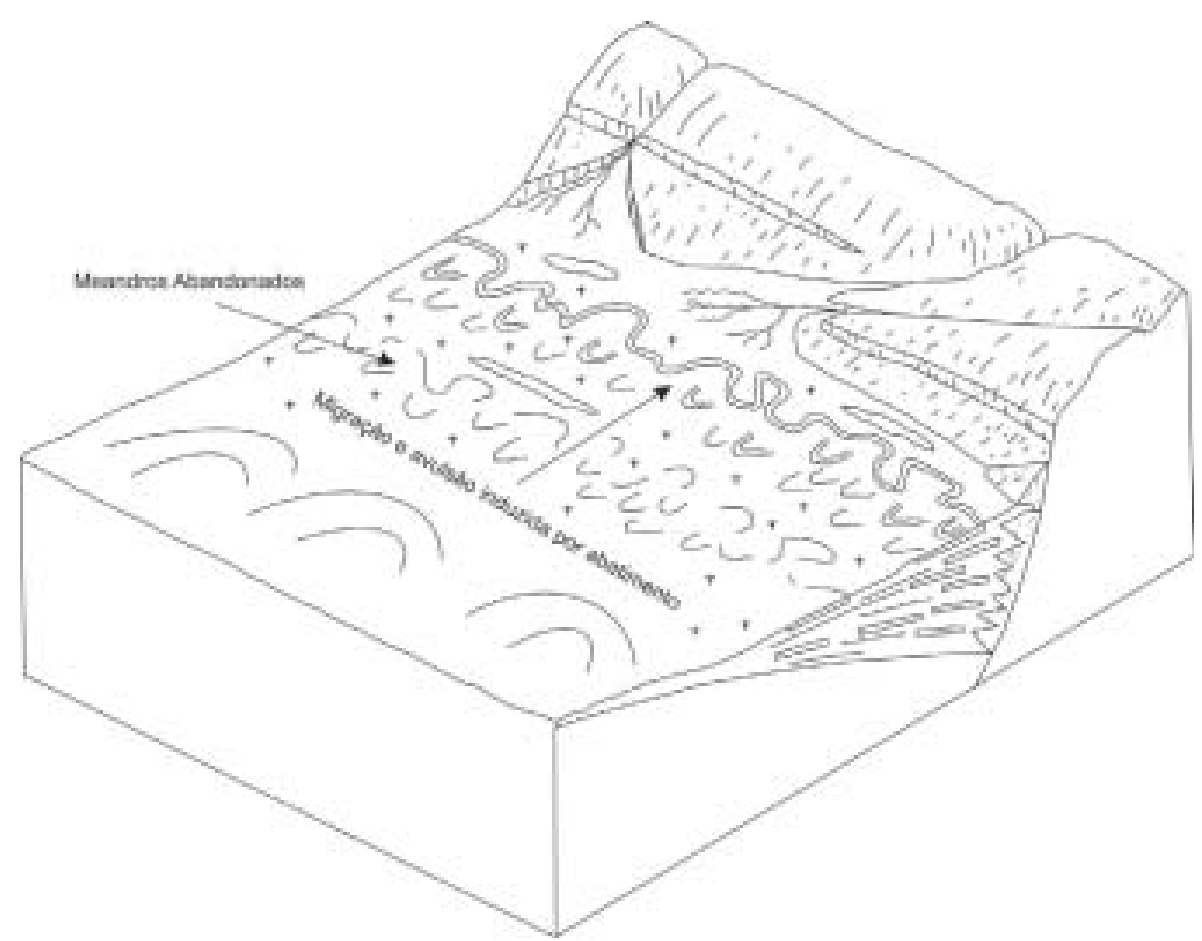

Figura 6-Modelo regional "Tilt blocks/Half grabens" (adaptado de Leeder \& Gawthorpe, 1989)

esquerda do Vale, em direção geral NW, explicando as extensas coberturas aluviais na margem direita e a sua quase ausência na margem esquerda. Esta tendência resultou na atual configuração do Domínios dos Patamares Rebaixados do Baixo rio Mandu e do Domínio dos Baixos Terraços e Várzea. O rebaixamento do nível de base, inclusive no Holoceno, condicionou os ciclos de entulhamento do vale principal, e os conseqüentes efeitos remontantes de represamento ao longo dos afluentes.

No vale do rio Turvo o condicionamento tectônico da dinâmica fluvial não difere das demais bacias estudadas, baseando-se em dois conjuntos de vetores principais:

- Soerguimento de blocos serranos

Assim como a Serra do Cervo e seu prolongamento NW (Serra das Águas), a Serra de Santa Catarina vem sofrendo pulsos de reativação acelerados no Cenozóico. Deste modo, foi configurado o Domínio Instável de Morros Fortemente Dissecados.

- Formação de hemi-graben

O soerguimento acelerado dos blocos serranos provocou a geração do Graben do Rio Turvo, de direção geral ENE-WSW, no baixo vale do rio Turvo e do ribeirão Areado. O médio vale dos rios está, por sua vez, em zonas subsidentes de direção SE-NW (falhas do Ciclo Uruçuano). Os ambientes subsidentes podem explicar a presença de remanescentes dos terraços mais antigos apenas nestes locais (ambientes mais preservados da erosão)

Os resultados demonstram que as calhas fluviais dos eixos principais das bacias estudadas vêm sendo "capturadas" por hemi-grabens gerados a partir do soerguimento de blocos serranos marginais (pulsos tectônicos). Ao constituírem-se em níveis de base locais, os grabens têm condicionado a migração lateral acelerada dos talvegues e a geração de várzeas com organização espacial anômala. O soerguimento diferencial de blocos vem sendo acompanhado do basculamento da morfologia para NW, acompanhando a tendência regional imposta pelo sistema Mantiqueira.

Não foram encontrados terraços nos vales dos rios Itaim e Lourenço Velho, afluentes do rio Sapucaí. Por outro lado, as várzeas apresentam configuração espacial semelhante às várzeas dos vales estudados, indicando o mesmo comportamento tectônico (soerguimento de bloco/efeitos distensivos gerando a captura do canal em hemi-grabens). A ausência de terraços pode ser associada com a elevada declividade e dissecação das encostas locais, assim como com a presença de um nível detrítico coluvial nas encostas.

Os resultados ilustram o fato da região ser considerada uma das zonas de maior freqüência de abalos sísmicos do país, com destaque para municípios como Campanha, Pouso Alegre, Poços de Caldas e Guaranésia (Berrocal et al, 1984).

Um estudo realizado em um recorte de cerca de $10.000 \mathrm{~km}^{2}$ da região sul de Minas Gerais, quantificando a freqüência e a área de topos em cartas topográficas 1 : 50.000 , demonstrou que apenas $26 \%$ dos topos situamse abaixo de $960 \mathrm{~m}$, sendo que cerca de $61 \%$ encontramse no intervalo entre 861 e 1240 m (Magalhães Jr e Trindade, 2004). Especificamente na bacia do rio do Cervo, os topos entre 850 e 1000 m ocupam a maior área, dos quais $56 \%$ estão entre 880 e 920 m (Fig. 7). Os terraços mais antigos encontrados nos três vales principais estudados, possuem altitudes máximas de $860 \mathrm{~m}$ (alguns terraços de afluentes possuem altitudes superiores). 


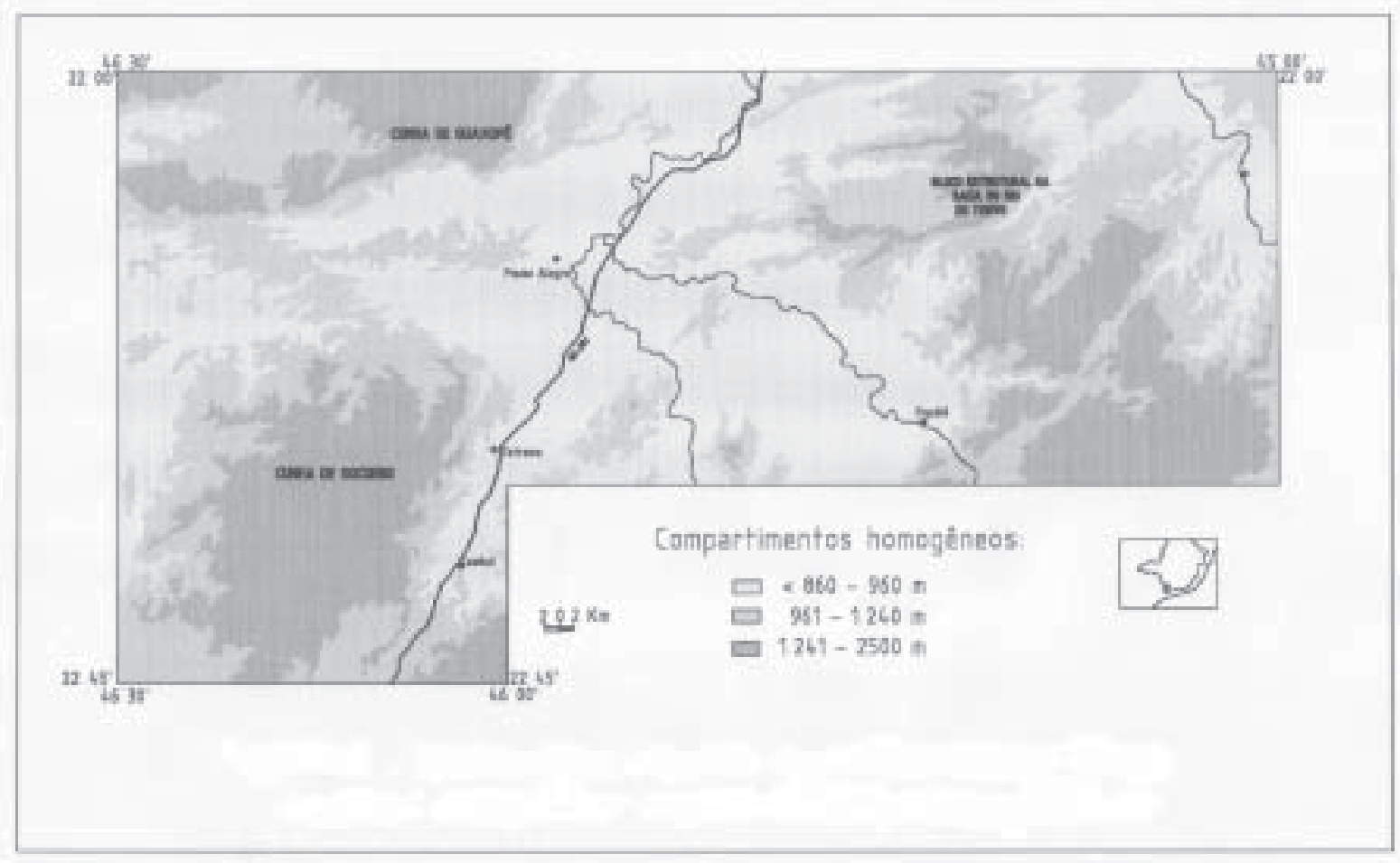

Figura 7 - Carta de Domínios Hipsométricos (Magalhães Jr. e Trindade, 2004)

Mesmo considerando a falta de dados e datações mais precisas, as propostas de Martonne (1940) e King (1956) sobre remanescentes de superfícies erosivas na região permitem algumas comparações com os domínios morfotectônicos identificados (Tab.4).

Uma das melhores correlações ocorre entre os topos das colinas e morros rebaixados dos vales principais (incluindo os Patamares Rebaixados do Baixo Rio Mandu), e os remanescentes do Ciclo Velhas de King (Superfície Neogênica de Martonne).

O arranjo espacial dos aspectos geomorfológicos e sua relação com o quadro geotectônico resultam em uma compartimentação transversal das três bacias em relação aos vales principais (N-S). A diferenciação ocorre, dentre outros, quanto à presença de focos de erosão acelerada e de cicatrizes de deslizamento (Tab. 5):

1) Nivel 1 (forte presença): blocos sujeitos a soerguimentos relativamente rápidos, como as serras de direção NE-SW.

2) Nível 2: áreas sujeitas ao soerguimento do Escudo Brasileiro, como as cunhas tectônicas.

3) Nivel 3 (fraca presença): zonas dos grabens ativos (encostas suaves). Apesar dos resultados evidenciarem o forte controle exercido pelo quadro geotectônico regional sobre a morfodinâmica cenozóica nas bacias estudadas, é preciso salientar, entretanto, que a atual compartimentação geomorfológica e a dinâmica fluvial resultaram da ação conjunta entre: a) processos morfodinâmicos determinados pelo clima úmido (relativamente estável durante o período); b) tectônica de soerguimentos e abatimentos diferenciais de blocos; c) ação humana, responsável pela elevação da carga sedimentar aos canais, alterando suas condições de energia e interferindo em seu padrão fluvial.

As atividades antrópicas ao longo dos últimos séculos, têm certamente modificado a dinâmica deposicional atual e a correlativa ao nível de várzea na região. Os desmatamentos, o uso e a ocupação inadequados e a extração de areia por meio de dragas, têm aumentado a carga sedimentar principalmente arenosa, provocando o entulhamento de leitos fluviais e o surgimento de barras de canal nas três bacias estudadas. $\mathrm{O}$ padrão fluvial dos cursos d'água principais tem, em vários trechos, se afastado do padrão meandrante típico, configurando-se atualmente como intermediário entre o meandrante e o entrelaçado.

\section{CONSIDERAÇÕES FINAIS}

A tectônica diferencial de blocos na região sul de Minas Gerais, ao longo do Cenozóico, vem respondendo a um contínuo soerguimento epirogenético marcado por pulsos episódicos que alteram a dinâmica fluvial das calhas principais. As variações de nível de base vêm impulsionando os cursos d'água a buscarem constantes adaptações aos "imputs" de energia e ao controle estrutural dos sistemas de falhas regionais. $\mathrm{O}$ aprofundamento das análises físicas $\mathrm{e}$ geoquímicas, envolvendo as características dos depósitos e a complexa datação dos níveis erosivos, poderá certamente vir a contribuir para a reconstituição do passado morfodinâmico da área. 
Tabela 4 - Relação entre Niveis Morfológicos e Superfícies Erosivas

\begin{tabular}{|c|c|c|c|c|}
\hline $\begin{array}{l}\text { Nível } \\
\text { (m) }\end{array}$ & $\begin{array}{l}\text { MARTONNE } \\
(1940)\end{array}$ & $\begin{array}{l}\text { KING } \\
(1956)\end{array}$ & IDADE & $\begin{array}{c}\text { Domín1os Morfotectôn1cos e } \\
\text { Alt1tudes Mếd1as }\end{array}$ \\
\hline$<861$ & $\begin{array}{l}\text { Superficie } \\
\text { Neogennica }\end{array}$ & $\begin{array}{c}\text { Ciclos } \\
\text { velhas e } \\
\text { paraguaçu }\end{array}$ & $\begin{array}{l}\text { Pleistoceno } \\
\text { Superior - } \\
\text { Holoceno }\end{array}$ & $\begin{array}{l}\text { Terraços e várzeas em grábens } \\
\text { sob entulhamento }(720-840 \mathrm{~m}) \text {. }\end{array}$ \\
\hline $\begin{array}{l}861- \\
960\end{array}$ & $\begin{array}{l}\text { Superficie } \\
\text { Neogênica }\end{array}$ & $\begin{array}{l}\text { Ciclo } \\
\text { velhas }\end{array}$ & $\begin{array}{c}\text { Plio- } \\
\text { pleistoceno }\end{array}$ & $\begin{array}{ll}\text { Morros e colinas rebaixados; } \\
\text { Patamares Rebaixados do Baixo } \\
\text { Rio Mandu }(880-920 \mathrm{~m})\end{array}$ \\
\hline $\begin{array}{l}961- \\
1240\end{array}$ & $\begin{array}{c}\text { Sup. Japi } \\
\text { ou das } \\
\text { Cristas } \\
\text { Médias }\end{array}$ & $\begin{array}{l}\text { Superficie } \\
\text { Sul- } \\
\text { Americana }\end{array}$ & Terciario & $\begin{array}{l}\text { Zona intermediária entre } \\
\text { bordas de blocos soerguidos e } \\
\text { zonas sob lento soerguimento } \\
\text { epirogenético ou abatimentos } \\
\text { de grábens; serra das Águas } \\
\text { (1100-1200 m) }\end{array}$ \\
\hline $\begin{array}{c}1241 \\
- \\
1360\end{array}$ & - & $\begin{array}{l}\text { Superfície } \\
\text { Pós- } \\
\text { Gondwana }\end{array}$ & Cretáceo & 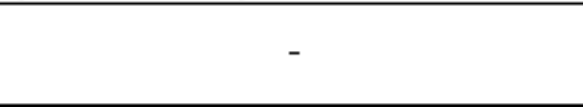 \\
\hline $\begin{array}{c}1361 \\
- \\
1500\end{array}$ & - & - & - & $\begin{array}{l}\text { Rebordos de blocos serranos } \\
\text { soerguidos e basculados; } \\
\text { Testemunhos soerguidos da sup. } \\
\text { Sul-Americana; Serra do cervo } \\
\langle 1300-1500 \mathrm{~m}\rangle ; \text { Serra de santa } \\
\text { Catarina }\langle 1400 \mathrm{~m}\rangle \\
\end{array}$ \\
\hline $\begin{array}{c}1501 \\
- \\
1620\end{array}$ & $\begin{array}{l}\text { Superfície } \\
\text { dos Campos }\end{array}$ & $\begin{array}{l}\text { Superficie } \\
\text { Gondwana }\end{array}$ & cretáceo & - \\
\hline $\begin{array}{c}1740- \\
1760\end{array}$ & - & - & - & $\begin{array}{l}\text { Blocos soerguidos (cunhas } \\
\text { tectonicas, sistema } \\
\text { Mantiqueira); possiveis } \\
\text { testemunhos soerguidos de } \\
\text { superficies. }\end{array}$ \\
\hline
\end{tabular}

Tabela 5 - Compartimentação das Bacias quanto à Incidência de Focos de Erosão Acelerada e Cicatrizes de Deslizamento

\begin{tabular}{|c|c|c|c|}
\hline Bac1a & Nível 1 (ma1or) & Nível 2 & $\begin{array}{lll}\text { Nivel } & 3 & \text { (menor) }\end{array}$ \\
\hline CERVO & $\begin{array}{c}\text { Serra do Cervo; } \\
\text { Cristas Meridionais }\end{array}$ & $\begin{aligned} \text { Morros e } & \text { Colinas da Margem } \\
& \text { Direita }\end{aligned}$ & $\begin{array}{c}\text { Domínio } \\
\text { Aplainado dos } \\
\text { Niveis } \\
\text { Deposicionais } \\
\text { Aluviais }\end{array}$ \\
\hline MANDU & $\begin{array}{l}\text { Morros e Conjuntos } \\
\text { serranos da Margem } \\
\text { Esquerda; "Canyon" } \\
\text { do Rib. do pantano }\end{array}$ & $\begin{array}{c}\text { Cristas e vertentes } \\
\text { orientadas da Margem } \\
\text { Direita }\end{array}$ & $\begin{array}{l}\text { Baixos Terraços } \\
\text { e varzea; } \\
\text { Patamares } \\
\text { Rebaixados do } \\
\text { Baixo rio Mandu }\end{array}$ \\
\hline TURVO & $\begin{array}{c}\text { Serra das Águas; } \\
\text { Dominio Instável de } \\
\text { Morros Fortemente } \\
\text { Dissecados }\end{array}$ & $\begin{array}{c}\text { Colinas e Morros } \\
\text { Rebaixados; } \\
\text { Serra de santa Catarina; } \\
\text { Dominio Meridional de } \\
\text { Morros Fortemente } \\
\text { Dissecados }\end{array}$ & $\begin{array}{c}\text { Baixo terraço e } \\
\text { várzea do rio } \\
\text { Turvo }\end{array}$ \\
\hline
\end{tabular}




\section{REFERÊNCIAS BIBLIOGRÁFICAS}

AB'SABER, A. N. ; BERNARDES, N. Vale do Paraíba, Serra da Mantiqueira e Arredores de São Paulo. In: CONGRESSO INTERNACIONAL DE GEOGRAFIA, 18, Rio de Janeiro. Guia de Excursões, 4. Rio de Janeiro: Conselho Nacional de Geografia, 1958. 303 p.

ALMEIDA, F.F.M. Fundamentos do Relevo Paulista. Transcrito de Geologia do Estado de São Paulo, boletim n ${ }^{\circ} 41$, 1964, Instituto Geográfico (SP).

São Paulo: IGEO-USP, 1974, 99 p. 1964.

ALMEIDA, F. F. M de O Cráton do Paramirim e suas Relações com o do São Francisco. In: SIMPÓSIO SOBRE O CRATON DO SÃO FRANCISCO E SUAS FAIXAS MARGINAIS, Salvador, 1979. Anais... Salvador, SME-BA/SBG-BA, 1981, p. $1-10$.

ARTUR, C. A. e WERNICK, E. Modelos Geotectônicos Aplicados ao Pré-Cambriano Superior do NE do Estado de São Paulo e Áreas Adjacentes do Estado de Minas Gerais: Uma Discussão. In: Geociências. vol. 12. n. 1.

BERROCAL, J. ASSUNPÇÃO, M.; ANTEZANA, R.; DIAS NETO, C. M.; ORTEGA, R.; FRANÇA, H.; São Paulo: UNESP, 1993, 155-185 pp.

BRAUN, O. P. G.; BAPTISTA, M. B. Considerações sobre a Geologia pré-cambriana da Região Sudeste e parte da Região Centro-Oeste do Brasil. In: REUNIÃO PREPARATÓRIA PARA O SIMPÓSIO SOBRE O CRÁTON DO SÃO FRANCISCO., 1977, Salvador. Anais... Salvador: SBG, Publ. Esp., 3, p. 225-350, 1978.

CAMPOS NETO, M. C. Orogenic Systems from Southwestern Gondwana: na approach to Brasiliano-Pan African Cycle and Orogenic Collage in Southeastern Brasil. In: CORDANI, U.G.; MILANI, E.J.; THOMAZ FILHO, A.; CAMPOS, D. A. (eds.). Tectonic Evolution of South America. Rio de Janeiro: International Geological Congress, 31, pp. 335$368,2000$.

CAVAlCANTE, J. C. et alii. Projeto Sapucaí; Estado de Minas Gerais e São Paulo. Relatório Final... Brasília: Departamento Nacional de Produção Mineral, Série Geologia, Seção Geológica Básica, 2, 1979, 299 p.

COMIG - Companhia Mineradora de Minas Gerais. Mapa Geológico do Estado de Minas Gerais. Escala 1: 1000000. Belo Horizonte: COMIG-CSRMG, 1994.

HASUI, Y.; FONSECA, M. J. G. \& RAMALHO, R. A Parte Central da Região de Dobramentos Sudeste e o Maciço Mediano de Guaxupé. In: SCHOBBENHAUS, C. (coord.) Geologia do Brasil - texto explicativo do mapa geológico do Brasil e da área oceânica adjacente. Escala 1:250.000. Brasília: DNPM, pp. 307-325, 1984.

IBGE. Geografia do Brasil - Região Sudeste. Rio de Janeiro: SERGRAF, FIBGE, vol. 3, 1977, 667 p.
KING, L. C. Geomorfologia do Brasil Oriental. Revista Brasileira de Geografia. Rio de Janeiro., v. 18, n. 2, p. 147-265, 1956

MAGALHÃES Jr, A. P.; TRINDADE, E. S. Condicionamento Tectônico da Dinâmica Fluvial Cenozóica do Vale do Rio do Cervo - Sul de Minas Gerais. In: SIMPÓSIO NACIONAL DE GEOMORFOLOGIA, 1, Uberlândia, 1996. Anais... Uberlândia: UFU, Departamento de Geografia, pp. 81-86, 1996.

MAGALHÃES Jr, A., P.; TRINDADE, E. S. Dinâmica Fluvial Quaternária no Vale do Rio do Cervo - Zona Rúptil Carandaí/ Mogi Guaçu - Sul de Minas Gerais. Geonomos. Belo Horizonte: CPMTC-IGC, vol. 5, n. 2, pp. 33-38, 1997.

MAGALHÃES Jr, A., P.; TRINDADE, E. S. Contribuições aos Estudos de Superfícies de Aplainamento a partir da Relação entre Níveis topográficos e Domínios Morfotectônicos na Região Sul de Minas Gerais. Revista Brasileira de Geomorfologia. Uberlândia: UGB, pp. 32-45, 2004.

MAGALHÃES Jr, A, P.; FERREIRA, A. Dinâmica Fluvial Quaternária em Zona de Cisalhamento - Bacia do Rio Turvo - Sul de Minas Gerais. Geosul. Florianópolis: Departamento de Geociências - CFH, vol. 14, n. 27, pp. 452- 456, 1998.

MAGALHÃES Jr, A, P.; TRINDADE, E. S. Morfodinâmica Fluvial Quaternária e Compartimentação Geomorfológica em Faixa Transicional entre Zona de Cisalhamento e Maciço Alóctone: A Bacia do Rio Mandu, Sul de Minas Gerais. Geosul. Florianópolis: Departamento de Geociências-CFH, vol. 14, n. 27, pp. 492-496, 1998.

MARTONNE, E. Problémes morphologiques du Brésil Tropical Atlantique. Annales de Géographie, (s. 1), 1, n. 277, 1940.

MORAES REGO, L. F. Notas sobre a Gomorfologia de São Paulo e sua Gênese. São Paulo: Instituto Astronômico Geofísico, 1932. 28 p.

RUELLAN, F. Comunicação sobre a Região Meridional de Minas Gerais e a Evolução do Vale do Paraíba. Boletim Geográfico. Rio de Janeiro: vol. 1, n. 8, pp. 99-104, 1953.

SAADI, A. Ensaio Sobre a Morfotectônica de Minas Gerais tensões intra-placa, descontinuidades crustais e morfogênese. Belo Horizonte: UFMG, 1991. 285 p. Tese (Prof. Titular) IGC, Universidade Federal de Minas Gerais, 1991.

Veloso, J. A. V. Sismicidade do Brasil. São Paulo: IAG $\backslash U S P \backslash C N E N, 320$ p., 1984.

WERNICK, E.; FIORI, A. P.; BETTENCOURT, J. S. ; CHOUDHURI, A. A Tectônica Rígida do Fim do Ciclo Brasiliano e sua Implicação na Estruturação da Borda Sul e Sudeste do Cráton do São Francisco: Tentativa de Um Modelo Preliminar. In: SIMPÓSIO SOBRE O CRÁTON DO SÃO FRANCISCO E SUAS FAIXAS MARGINAIS, 1, Salvador, 1979. Anais...Salvador: SME-BA $\backslash$ SBG-BA, p. 164-168, 1981. 